\title{
Neto2 Assembles with Kainate Receptors in DRG Neurons during Development and Modulates Neurite Outgrowth in Adult Sensory Neurons
}

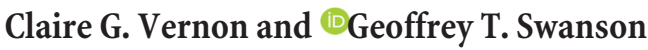 \\ Department of Pharmacology, Northwestern University Feinberg School of Medicine, Chicago, Illinois 60611
}

Peripheral sensory neurons in the dorsal root ganglia (DRG) are the initial transducers of sensory stimuli, including painful stimuli, from the periphery to central sensory and pain-processing centers. Small- to medium-diameter non-peptidergic neurons in the neonatal DRG express functional kainate receptors (KARs), one of three subfamilies of ionotropic glutamate receptors, as well as the putative KAR auxiliary subunit Neuropilin- and tolloid-like 2 (Neto2). Neto2 alters recombinant KAR function markedly but has yet to be confirmed as an auxiliary subunit that assembles with and alters the function of endogenous KARs. KARs in neonatal DRG require the GluK1 subunit as a necessary constituent, but it is unclear to what extent other KAR subunits contribute to the function and proposed roles of KARs in sensory ganglia, which include promotion of neurite outgrowth and modulation of glutamate release at the DRG- dorsal horn synapse. In addition, KARs containing the GluK1 subunit are implicated in modes of persistent but not acute pain signaling. We show here that the Neto2 protein is highly expressed in neonatal DRG and modifies KAR gating in DRG neurons in a developmentally regulated fashion in mice. Although normally at very low levels in adult DRG neurons, Neto2 protein expression can be upregulated via MEK/ERK signaling and after sciatic nerve crush and Neto $2^{-1-}$ neurons from adult mice have stunted neurite outgrowth. These data confirm that Neto2 is a bona fide KAR auxiliary subunit that is an important constituent of KARs early in sensory neuron development and suggest that Neto2 assembly is critical to KAR modulation of DRG neuron process outgrowth.

Key words: auxiliary subunit; axon outgrowth; ionotropic glutamate receptor; nociceptor; pain; voltage-clamp

Significance Statement

Pain-transducing peripheral sensory neurons of the dorsal root ganglia (DRG) express kainate receptors (KARs), a subfamily of glutamate receptors that modulate neurite outgrowth and regulate glutamate release at the DRG-dorsal horn synapse. The putative KAR auxiliary subunit Neuropilin- and tolloid-like 2 (Neto2) is also expressed in DRG. We show here that it is a developmentally downregulated but dynamic component of KARs in these neurons, that it contributes to regulated neurite regrowth in adult neurons, and that it is increased in adult mice after nerve injury. Our data confirm Neto2 as a KAR auxiliary subunit and expand our knowledge of the molecular composition of KARs in nociceptive neurons, a key piece in understanding the mechanistic contribution of KAR signaling to pain-processing circuits.

\section{Introduction}

Kainate receptors (KARs), a subfamily of ionotropic glutamate receptors, modulate circuit activity and excitatory/inhibitory bal-

Received Sept. 22, 2016; revised Feb. 9, 2017; accepted Feb. 16, 2017.

Author contributions: C.G.V. and G.T.S. designed research; C.G.V. performed research; C.G.V. and G.T.S. analyzed data; C.G.V. and G.T.S. wrote the paper.

This work was supported by the National Institute of Neurological Disorders and Stroke-National Institutes of Health (Grant R01NS071952 to G.T.S.) and a Julius B. Kahn Fellowship (C.G.V.). Imaging was performed at the Northwestern University Center for Advanced Microscopy generously supported by National Cancer Institute Cancer Center Support Grant P30 CA060553 awarded to the Robert H. Lurie Comprehensive Cancer Center. Behavioral assays were performed at the Northwestern University Behavioral Phenotyping Core Facility.

The authors declare no competing financial interests.

Correspondence should be addressed to Geoffrey T. Swanson, Department of Pharmacology, Northwestern University Feinberg School of Medicine, 320 E. Superior St., Chicago, IL 60611. E-mail: gtswanson@northwestern.edu. ance throughout the nervous system (Contractor et al., 2011). KARs assemble as a diverse array of heteromeric proteins found at both presynaptic and postsynaptic sites. Five pore-forming subunits (GluK1-GluK5) form the tetrameric core of these receptors, which differ in their biophysical properties and neuronal distribution depending on their subunit composition (Contractor et al., 2011). In addition, the Neuropilin- and tolloid-like (Neto) proteins, Neto1 and Neto2, affect KAR biophysical properties and localization (Ng et al., 2009; Zhang et al., 2009; Copits et al., 2011; Straub et al., 2011b; Tang et al., 2011). Both Neto 
proteins alter recombinant KAR properties but, to date, only Neto1 has been established as a constituent of native KARs (Straub et al., 2011b; Tang et al., 2011). Modulation of native receptors represents a critical criterion that distinguishes between putative and validated auxiliary subunits (Yan and Tomita, 2012). Therefore, Neto 2 has yet to be confirmed as a bona fide KAR auxiliary subunit despite the robust effects of recombinant Neto2 on KAR properties in heterologous expression systems and cultured neurons (Zhang et al., 2009; Copits et al., 2011; Straub et al., 2011a; Tang et al., 2012; Sheng et al., 2015; Palacios-Filardo et al., 2016).

KARs are expressed throughout the nervous system, including in small-diameter non-peptidergic neurons located in the dorsal root ganglia (DRG), which are presumed to be nociceptors based on their molecular profile and their slow conduction velocity (Agrawal and Evans, 1986; Huettner, 1990; Lee et al., 2001; Usoskin et al., 2015). GluK1 mRNA is expressed in DRG at high levels (Bettler et al., 1990; Partin et al., 1993) and KAR currents and calcium signals are dependent on expression of the GluK1 subunit (Mulle et al., 2000; Rozas et al., 2003). Glutamate-evoked currents in DRG neurons have properties similar to GluK1containing receptors (Swanson and Heinemann, 1998), although there is evidence for GluK5 mRNA (Herb et al., 1992; Partin et al., 1993) and Neto mRNA in DRG (Allen Institute for Brain Science, 2015).

The role of KARs in peripheral neurons is diverse. They act as autoreceptors at central terminals to modulate glutamate release onto dorsal horn neurons (Kerchner et al., 2001b; Kerchner et al., 2002) and their activation affects neurite outgrowth in culture (Joseph et al., 2011; Marques et al., 2013). Peripheral KARs are thought to serve as glutamate sensors during inflammation or tissue damage (Du et al., 2006) and somatic KARs might sense glutamate released within the ganglia (Kung et al., 2013). GluK1containing KARs also modulate pathologic pain, although this function does not necessarily arise from the KAR population in DRG neurons (Wu et al., 2005; Koga et al., 2012), and pharmacological inhibition or genetic ablation of GluK1 alleviates diverse models of hypersensitive pain in rodents (for review, see Bhangoo and Swanson, 2013). Although the obligatory role of the GluK1 subunit is clear, to what extent additional pore-forming or auxiliary subunits contribute to these receptors is not understood. Moreover, the physiological properties of KARs in adult DRG neurons, and how those might differ from neonatal receptors, have not been characterized despite their relevance to nociception and other activities. A better understanding of the molecular composition of KARs will be critical to targeting receptors successfully for the treatment of pathological pain.

We confirm here that Neto2 is a bona fide KAR auxiliary subunit and a component of KARs in peripheral sensory neurons. Neto2 expression is highest in the first postnatal week, reducing to low levels $\sim 2$ weeks after birth. Adult neurons retain the capacity for high Neto2 expression, however, and their outgrowth in culture is altered in the absence of Neto2. In addition, Neto2 is upregulated after crush injury to the sciatic nerve. These findings show that Neto2 is a developmentally regulated component of KARs in the peripheral nervous system and is regulated dynamically in adult neurons during axon outgrowth.

\section{Materials and Methods}

Animals. All animals used in these studies were treated according to protocols approved by Northwestern University's Institutional Animal Care and Use Committee, which were consistent with standards of care established by the Guide for the Care and Use of Animals, 8th edition, published by the National Institutes of Health in 2011. Male and female mice were used for all experiments; no gender-dependent differences were observed, so data from both genders was combined. For physiology and biochemical experiments, wild-type animals were C57BL/6 from Charles River Laboratories and The Jackson Laboratory or were the wildtype littermates of the knock-out animals used. For outgrowth and behavioral experiments, wild-type animals were the littermates of the Netol knock-out $\left(\mathrm{Neto1}^{-/-}\right.$) and Neto2 ${ }^{-/-}$mice that were generously provided to us by Dr. Roderick McInnes (Ng et al., 2009; Tang et al., 2011). GluK5 ${ }^{-1-}$ mice were provided by Dr. Anis Contractor (Contractor et al., 2003). For all experiments, neonatal animals were between postnatal day 0 (P0) and P5, adult animals were P56 (8 weeks) and older, and all other ages are specified.

Dissection and neuron culture. DRG neuron cultures were performed as described previously (Copits et al., 2014). Briefly, mice were anesthetized with isoflurane and rapidly decapitated. DRG were removed and cleaned of nerve processes and connective tissue. For electrophysiology, only lumbar ganglia were removed; for imaging and Western blotting, lumbar and thoracic ganglia were removed. Tissue was digested at $37^{\circ} \mathrm{C}$ in collagenase $\mathrm{A} / \mathrm{D}$ ( $1 \mathrm{mg} / \mathrm{ml}$ neonatal DRG, $3-5 \mathrm{mg} / \mathrm{ml}$ adult DRG), followed by $0.4 \mathrm{mg} / \mathrm{ml}$ activated papain (Roche). DRG were plated to poly-L-lysine/ laminin-coated glass coverslips in 50:50 DMEM:F12 medium (Corning) containing 10\% fetal bovine serum (Gemini Bio-Products,) and $0.5 \%$ penicillin/streptomycin (Corning). Cells were plated in a minimal volume $(100-200 \mu \mathrm{l})$ to each coverslip and wells were filled with medium after $2 \mathrm{~h}$ of culture. At this time, nerve growth factor $(10 \mathrm{ng} / \mathrm{ml}$ ) (Promega) was added to adult cultures and U0126 (Abcam), triciribine (Sigma-Aldrich), and wortmannin (Sigma-Aldrich) were added as noted in the Results section.

Western blotting. Total solubilized protein was separated on a $10 \%$ denaturing polyacrylamide gel and transferred to a polyvinylidene fluoride membrane. Neto2 was detected using rabbit anti-Neto2 (1:2000, catalog \#ab109288, RRID:AB_10863520; Abcam). Actin was detected using mouse anti-actin (1:2000, catalog \#A4700, RRID:AB_476730; Sigma-Aldrich). Goat anti-rabbit and goat anti-mouse HRP-conjugated secondary antibodies were from Thermo Fisher Scientific catalog \#31460, RRID:AB_228341, and catalog \#31430, RRID:AB_228307, respectively).

Imaging and neurite outgrowth quantification. To visualize and quantify neuron axon outgrowth, dissociated neurons were electroporated with eGFP using the MaxCyte Electroporation System immediately before plating. Twenty-four hours after plating, neurons were fixed in $4 \%$ PFA for $1 \mathrm{~h}$ by gently exchanging the growth medium for PBS in four $50 \%$ volume exchanges, then exchanging the PBS for PFA in four $50 \%$ volume exchanges. PFA was again exchanged for PBS and coverslips were mounted in ProlongGold mounting medium (Invitrogen) and dried overnight. DRG neurons were identified by their large, bright, round somas and were imaged on a Nikon AR1 laser scanning microscope at the Northwestern University Center for Advanced Microscopy. Confocal image stacks were flattened and neurite arbors were traced using the Simple Neurite Tracer plugin in FIJI (Fiji Is Just ImageJ, RRID: SCR_002285; Schindelin et al., 2012). Arbor information was exported to Excel and automated Sholl analysis was performed at $5 \mu \mathrm{m}$ intervals in the Simple Neurite Tracer, exported to Excel, and statistics performed in Prism 5 (GraphPad Software). For statistical comparisons between equivalent maturation stages, cells were categorized as described previously (Marques et al., 2013). After analysis, defined parameters for each maturation stage were determined by evaluating cells in each stage from both genotypes combined. Cells with $>60$ branch points were Stage 2 regardless of the length of their longest axon. Cells with 60 or fewer branch points were categorized as Stage 1 if their longest axon was 150 $\mu \mathrm{m}$ long or less and as Stage 3 if their longest axon was $>150 \mu \mathrm{m}$ long. The experimenter was blinded to genotype for the dissection, culture, imaging, tracing, and analysis of all cells.

Electrophysiology. Whole-cell recordings from acutely isolated DRG neurons were performed as described previously (Copits et al., 2014). Currents were elicited by fast application of $10 \mathrm{~mm}$ glutamate (SigmaAldrich) to lifted cells using a piezoceramic system; rise times (10-90\%) ranged from 0.5 to $3.0 \mathrm{~ms}$. Weighted desensitization rates and relative proportions were calculated from biexponential fits of current decays 
during a $1 \mathrm{~s}$ application of glutamate using Clampfit10 (Molecular Devices). Recordings were made and agonist was applied in our standard external solution containing the following (in $\mathrm{mm}$ ): $150 \mathrm{NaCl}, 2.8 \mathrm{KCl}$, $1.8 \mathrm{CaCl}_{2}, 1.0 \mathrm{MgCl}_{2}, 10$ glucose, and 10 HEPES, adjusted to $\mathrm{pH}$ 7.3. Intracellular solution contained the following (in mM): $95 \mathrm{CsF}, 25 \mathrm{CsCl}$, $2 \mathrm{NaCl}, 10$ HEPES, 10 EGTA, $2 \mathrm{Mg}$-ATP, 10 QX-314, 5 TEA-Cl, and 5 4-aminopyridine, adjusted to $\mathrm{pH} 7.3$ with $\mathrm{CsOH}$. To isolate KAR currents in adult neurons, AMPAR and NMDAR were blocked with $50 \mu \mathrm{M}$ each of GYKI53655 (Tocris Bioscience) and D-APV (Abcam). Acutely isolated neonatal neurons do not express detectible AMPAR or NMDAR currents before growing axons (Lovinger and Weight, 1988; Huettner, 1990). We confirmed this by recording glutamate-evoked currents from a subset of neonatal neurons in the presence of GYKI53655 and D-APV; no difference in current amplitudes or desensitization rates was observed compared with the absence of antagonists. Therefore, most neonatal KAR currents were evoked in the absence of antagonists.

Behavior. The experimenter was blinded to genotype and injection (formalin or saline) for all behavioral experiments, which were performed as described previously (Qiu et al., 2011). Briefly, thermal sensory thresholds were determined by Hargreaves test on a Plantar Test Hargreaves Apparatus from Ugo Basile; a cutoff time of $15 \mathrm{~s}$ was set to avoid tissue damage. Mechanical sensory thresholds were determined using increasing weights of von Frey sensory evaluator filaments (North Coast Medical). Nocifensive reactions to three of five trials was considered a response and that filament weight was recorded as threshold. For formalin-induced inflammation, $10 \mu \mathrm{l}$ of saline or $5 \%$ formalin in saline was injected subcutaneously into the left hindpaw plantar. Immediately after formalin injection, mice were placed in an observation chamber. The amount of time spent biting, licking, or shaking the paw was measured and data were pooled into $5 \mathrm{~min}$ bins. Total observation time was $60 \mathrm{~min}$. Mice were habituated to the experimental chamber for $30 \mathrm{~min}$ before beginning any experiment.

Sciatic nerve crush. The sciatic nerve was crushed as described previously (Decosterd et al., 2002). Briefly, adult male and female C57BL/6 mice were brought to a surgical plane of anesthesia with ketamine/xylazine and the sciatic nerve was exposed at midthigh level. The nerve was crushed proximal to the trifurcation with a pair of hemostat forceps for $30 \mathrm{~s}$. For sham animals, the nerve was exposed for $30 \mathrm{~s}$ without crush. Three, 7 , and $10 \mathrm{~d}$ after surgery, the L3-L5 ganglia and the attached nerve to the trifurcation were recovered and homogenized for Western blotting.

Statistical methods. Comparisons between two sets of data were performed with an unpaired $t$ test. One-sample $t$ tests evaluated the difference between samples and a theoretical mean of 1.0 and were used to determine significance of the fold change from baseline values. Data consisting of three or more groups were analyzed by one-way ANOVA, followed by Tukey's post hoc comparison. Confidence intervals $(95 \%$ CIs) of proportions were calculated with the modified Wald method and total numbers of KAR-positive and KAR-negative cells were compared using a $\chi^{2}$ test. All other data are presented as mean \pm SEM. Sholl curves were analyzed by two-way ANOVA, followed by Bonferroni post hoc comparison. Spearman's or Pearson's correlation was used to evaluate correlations between time spent in culture and desensitization kinetics, based on results from Krustal-Wallis normality test performed in Origin software (OriginLab). All other statistical tests were performed in Prism 5 software (GraphPad Software).

\section{Results}

How the putative KAR auxiliary subunit Neto2 contributes to KAR signaling in the central and peripheral nervous systems is unknown. To address this question, we first identified neurons that expressed Neto2 mRNA and which were known to have detectable KAR currents. One such population of neurons was found in DRG using the publicly available in situ hybridization data from the Allen Spinal Cord Atlas (Allen Institute for Brain Science, 2015), which showed Neto2 transcription in DRG tissue from P4 mice (Fig. 1a). Consistent with the Allen Spinal Cord Atlas data, Neto 2 protein was detected in Western blots from wild-type P3 DRG but not from DRG isolated from Neto2 ${ }^{-/-}$ mice (Fig. 1b). We also observed that Neto2 was most highly expressed at the earliest neonatal ages tested and was downregulated over development, plateauing at a barely detectable level of immunoreactivity by 2 weeks after birth and remaining low through adulthood (Fig. 1c,d; percentage of P2 expression: P5 = $62 \pm 14 \%, \mathrm{P} 10=55 \pm 10 \%, \mathrm{P} 14=24 \pm 10 \%$, adult $=12 \pm 3 \%$, $n=3$, repeated-measures ANOVA, $p<0.0001$ ).

We hypothesized that reduced Neto 2 might alter KAR subunit composition and current properties in adult neurons compared with neonatal neurons. To test this possibility, glutamate $(10 \mathrm{mM}$, $100 \mathrm{~ms}$ ) was fast-applied to dissociated neurons of small to medium diameter to elicit KAR currents from acutely dissociated adult and neonatal wild-type neurons. Fitting of the current decay with either a one- or two-component exponential function yielded a mean weighted tau of $8.2 \pm 1.2 \mathrm{~ms}(n=42)$ in adult neurons, more than twice as fast as the $20.2 \pm 3.7 \mathrm{~ms}(n=18)$ glutamate-evoked desensitization rate from neonatal neurons $(p=0.0063$ ) (Fig. 1d,e). The adult neuron population also had smaller peak amplitudes $(85 \pm 9 \mathrm{pA}, n=43)$ than were seen in neonatal neurons $(229 \pm 29 \mathrm{pA}, n=22)(p<0.0001$; Fig. $1 d, f)$.

We next tested whether Neto 2 is indeed a component of KARs by comparing glutamate-evoked currents in DRG neurons acutely isolated from wild-type and Neto $2^{-1-}$ mice (Tang et al., 2011). Consistent with previous studies, glutamate elicited rapidly desensitizing currents in $71 \%$ of neonatal wild-type neurons recorded $(95 \% \mathrm{CI}=53-85 \%)$ and $46 \%$ of neonatal Neto $2^{-1-}$ neurons (95\% CI $\left.=30-62 \%, \chi^{2} p=0.1358, \mathrm{df}=3\right)($ Fig. $2 a, b)$. KAR currents in neonatal wild-type neurons exhibited somewhat variable desensitization kinetics (Figs. 1e, 2d), an observation supported by a high coefficient of variation $(\mathrm{CV})$ of 0.78 for the fitted time course of desensitization. This intercell variability in neonatal neurons depended on genotype (Bartlett's test, $p<$ $0.0001)$ and was much lower $(0.35)$ in neurons isolated from Neto $2^{-1-}$ mice, which showed an $\sim 10$-fold faster KAR desensitization rate of $2.1 \pm 0.2 \mathrm{~ms}(n=14, p<0.0001$ with a Tukey's multiple-comparison test; Fig. 2c). KAR currents in neurons from Neto $2^{-I-}$ mice also exhibited much lower peak amplitudes of their glutamate-evoked currents $(28 \pm 4 \mathrm{pA}, n=14)$ compared with wild-type $(p<0.0001$; Fig. $2 e, f)$ and the CV for Neto $2^{-l-}$ current amplitudes $(0.48)$ was lower than for wild-type neurons (0.60). These results support a role for Neto2 auxiliary proteins in shaping KARs in DRG neurons.

The very rapid desensitization of currents during glutamate application to Neto $2^{-/-}$neurons appeared similar in time course to recombinant GluK1/GluK5-containing heteromeric KARs (Herb et al., 1992; Swanson et al., 1998). GluK5 is transcribed in both DRG and trigeminal ganglia and was suggested to assemble into KARs in trigeminal neurons (Sahara et al., 1997). We tested the inclusion of GluK5 in DRG KARs in additional comparative recordings of glutamate-evoked currents in neurons from GluK5 ${ }^{-1-}$ mice. KAR currents were evoked from $52 \%$ of neonatal GluK5 ${ }^{-1-}$ neurons (95\% CI $=35-68 \%$; Fig. $2 a, b$ ) and exhibited significantly slower desensitization $(39.5 \pm 3.5 \mathrm{~ms})$ and larger current amplitudes $(449 \pm 51 \mathrm{pA})$ relative to recordings from wild-type neurons $(n=15 ; p<0.0001$ for both measures relative to wild-type; Fig. $2 c-f$ ). In addition, the relative variability of currents evoked from GluK5 $5^{-/-}$neurons was more similar to Neto $2^{-1-}$ neurons than to wild-type in that the CV was 0.34 for desensitization rates and 0.44 for peak current amplitudes. Although the Allen Spinal Cord Atlas shows Neto1 mRNA in P4 DRG (Allen Institute for Brain Science, 2015), we found no evidence of Netol assembly into KARs in neonatal DRG neurons. 
a

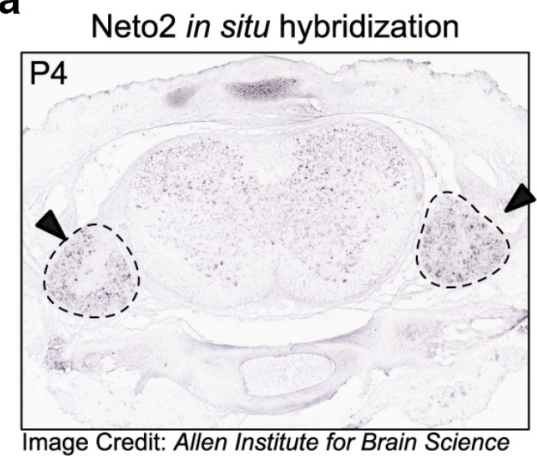

b

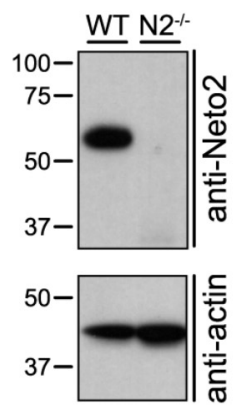

C

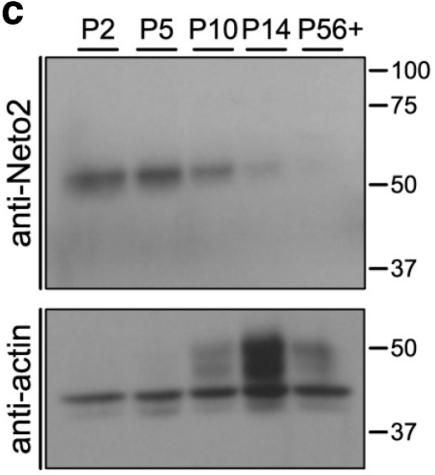

d

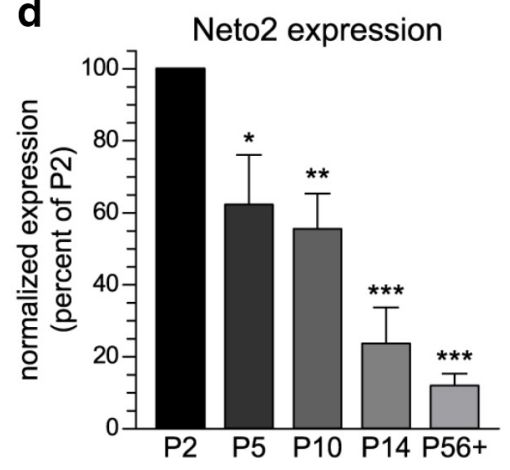

e

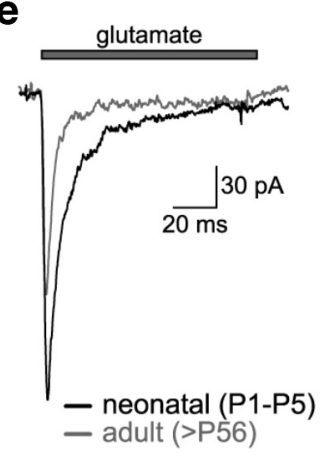

f

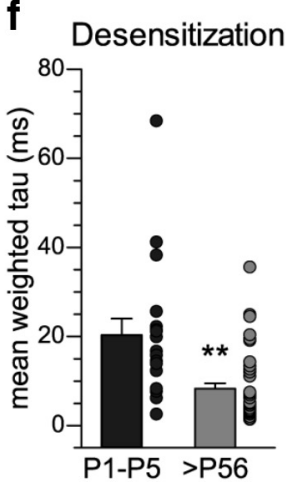

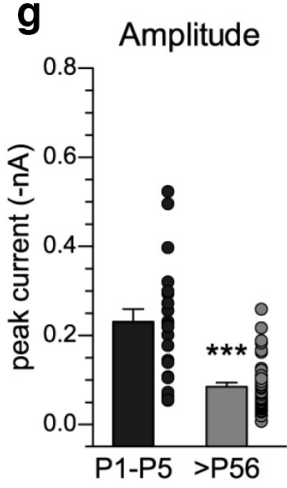

Figure 1. Net02 is highly expressed in neonatal DRG and downregulated over development. $\boldsymbol{a}$, In situ hybridization in a P4 spinal section with a probe directed against Net02 transcripts. DRG are outlined with the dotted lines and denoted by arrowheads. $\boldsymbol{b}$, Neto2 protein is detected by Western blot in wild-type but not Net02 ${ }^{-1-}$ DRG homogenate. c, Representative Western blot showing Neto 2 protein expression from acutely homogenized P2, P5, P10, P14, and adult DRG. $\boldsymbol{d}$, Densitometry quantification of Neto2 expression normalized to actin represented as percentage of Net02 expression at P2. $\boldsymbol{e}$, Representative current traces from neonatal and adult wild-type DRG neurons. Gray bar indicates glutamate $(10 \mathrm{~mm})$ application. Currents are reproduced from Figure $2 a$ (neonatal) and Figure $3 a$ (adult) for comparison. $f$, Quantification of mean weighted tau of glutamate-evoked desensitization for neonatal and adult DRG neurons. $\boldsymbol{g}$, Quantification of peak current amplitude for neonatal and adult DRG neurons. ${ }^{*} p<0.05$; ${ }^{* *} p<0.01 ;{ }^{* * *} p<0.001$.

KAR currents were elicited from $41 \%$ of $\mathrm{Neto1}^{-1-}$ neurons ( $95 \%$ $\mathrm{CI}=23-64 \%$, Fig. $2 a, b)$ and, similar to wild-type neurons, the mean weighted tau of desensitization was $20.4 \pm 4.0 \mathrm{~ms}(n=11$, $p>0.05$ ) (Fig. $2 c, d$ ). Peak current amplitudes in $\mathrm{Netol}^{-1-}$ neurons were $236 \pm 44 \mathrm{pA}(n=11, p>0.05$ compared with wildtype) (Fig. $2 c, e$ ). Intercell variability in currents evoked from $\mathrm{Neto}^{-1-}$ neurons was similar to wild-type neurons with a CV of 0.66 for the mean weighted tau and 0.62 for peak current amplitudes. These results are consistent with the interpretation that neonatal wild-type neurons express KARs composed of the GluK1, GluK5, and Neto2 subunits.

Our data suggest that Neto2 could be the principal component that differentiates properties of neonatal and adult DRG KARs. To test this, we evoked KARmediated currents in adult neurons from wild-type and knock-out mice. Because adult neurons grew processes more slowly than neonatal neurons, we were able to lift and record from healthy adult neurons over a longer time span (3-22 h) than for neonatal neurons $(3-12 \mathrm{~h})$ while still achieving the solution exchange required to resolved rapid glutamate-evoked currents (example traces are shown in Fig. $3 a)$. Adult wild-type neurons had KAR currents in 54\% of small- and mediumdiameter neurons (95\% CI $=43-64 \%$ ), which was similar in all the genotypes examined (Fig. 3b). Notably, we observed a time-in-culture-dependent slowing of KAR current desensitization in adult neurons. That is, in the first $12 \mathrm{~h}$ after plating, currents from wild-type cells desensitized with a mean weighted tau of $3.1 \pm 0.3 \mathrm{~ms}$ $(n=16)$, similar to the decay rate that we observed in adult Neto2 ${ }^{-1-}$ neurons in this same time frame $(2.2 \pm 0.2 \mathrm{~ms}, n=$ $15, p>0.05)$. At later time points, however, neurons with more slowly desensitizing kinetics emerged in cultures from adult wild-type mice, shifting the mean desensitization rate to $12.6 \pm 1.9 \mathrm{~ms}(n=$ $22, p<0.001$ vs adult wild-type neurons recorded 3-12 h after dissociation; Fig. $3 c, d)$. The slower desensitization of currents in wild-type neurons was accompanied by greater variability $(\mathrm{CV}=0.70)$ compared with those recorded at $<12 \mathrm{~h}$ in culture $(\mathrm{CV}=0.33)$. In contrast, currents evoked from Neto2 ${ }^{-1-}$ neurons desensitized rapidly at later time points $(2.5 \pm 0.2$ ms, $n=17 ; p<0.0001$ vs wild-type $12-22$ $\mathrm{h}, p>0.05$ vs wild-type $3-12 \mathrm{~h}$ ) and the variability of desensitization kinetics remained relatively low (Fig. $3 c, d$ ). There was a positive correlation between the mean weighted tau of desensitization and the time wild-type neurons spent in culture before the recordings $(n=38, r=$ $0.7728, p<0.0001$ Spearman's correlation) that was not seen for adult Neto $2^{-1-}$ neurons $(n=32, r=0.1450, p=0.2143$ Pearson's correlation) (Fig. 3g). These data underscore the difference in KAR current properties between neonatal and adult sensory neurons and demonstrate that Neto2 incorporation critically distinguishes KARs at different ages. In addition, the data suggest that Neto2 incorporation increases over time in adult sensory neuron cultures.

Consistent with this interpretation, current amplitudes in wildtype adult neurons increased from $62 \pm 10 \mathrm{pA}$ at $3-12 \mathrm{~h}$ after plating to $109 \pm 13 \mathrm{pA}$ at $12-22 \mathrm{~h}(p<0.05)$. Current amplitudes in Neto $2^{-/-}$neurons were $38 \pm 4 \mathrm{pA}$ at $3-12 \mathrm{~h}$ and $19 \pm 2 \mathrm{pA}$ after $12-22 \mathrm{~h}$ in culture, which were similar to currents from wild-type 
neurons at early time points $(p>0.05)$ but significantly different from recordings made $>12 \mathrm{~h}$ after plating the cells $(p<$ 0.001) (Fig. 3e,f). We detect a modest but significant positive correlation of wild-type peak current amplitudes with time in culture $(r=0.3755$ and $p=0.0092)$ that was not observed in Neto $2^{-1-}$ neurons $(r=$ $-0.7660, p>0.05$ ) (Fig. 3h), supporting our interpretation that Neto 2 incorporation into KARs increases in adult neurons over time in culture.

As in neonatal neurons, fast desensitization of currents evoked from Neto $2^{-1-}$ and early wild-type neurons was suggestive of GluK5 subunit incorporation. KAR currents evoked in GluK5 ${ }^{-1-}$ neurons desensitized with a mean weighted tau of $9.3 \pm 2.1 \mathrm{~ms}(n=18)$ (Fig. $3 c)$. The presence of two somewhat distinct groups of desensitization rates, as reflected in the cumulative probability plot (Fig. $3 d$ ), produced a very high CV of 0.97 ; accordingly, the mean weighted tau of GluK5 ${ }^{-1-}$ currents at 3-12 $\mathrm{h}$ was not different from wild-type decay either at early or at late time points $(p>0.05$ for both comparisons). From 12 to $22 \mathrm{~h}$, GluK5 ${ }^{-1-}$ neurons had a mean weighted tau of $19.4 \pm$ $4.9 \mathrm{~ms}$, similar to wild-type neurons at late, rather than early, time points $(p>$ 0.05 and $p<0.001$, respectively; Fig. $3 c, d$ ). In addition, the desensitization rate was not positively correlated with time in culture in GluK5 ${ }^{-/-}$neurons $(r=0.3120$, $p=0.0787$, Spearman's correlation, data not shown), unlike currents in wild-type neurons. KAR current amplitudes from adult GluK5 $5^{-1-}$ neurons were similar to those in wild-type neurons $(89 \pm 13 \mathrm{pA}$ from 3 to $12 \mathrm{~h}$ and $109 \pm 15 \mathrm{pA}$ from 12 to $22 \mathrm{~h}, p>0.05$ compared with wild-type) (Fig. $3 e, f)$. These data support the interpretation that GluK5 incorporates into adult DRG KARs, perhaps with some degree of heterogeneity.

Similar to neonatal neurons, we did not find evidence for Netol incorporation into adult KARs. The $40 \%$ of Neto $1^{-1-}$ neurons with KAR-mediated currents $(95 \% \mathrm{CI}=$ 26-55\%, Fig. 3b) exhibited fast desensitization kinetics of $3.1 \pm 1.0 \mathrm{~ms}$ in the first $12 \mathrm{~h}$ after dissociation $(n=4)$ and cells with slower desensitization kinetics emerged from 12 to $22 \mathrm{~h}$, shifting the mean desensitization rate to $13.1 \pm 3.6 \mathrm{~ms}(n=8)$ (Fig. $3 c, d)$. Like adult wild-type neurons, Neto $1^{-1-}$ desensitization rates correlated positively with the time neurons spent in culture $(r=0.8601, p=0.0002$, Spearman's correlation, data not shown) and peak current amplitudes of $81 \pm 8 \mathrm{pA}$ at early and $83 \pm 17 \mathrm{pA}$ at late time points were not different from wild-type $(p>0.05)$ (Fig. $3 e, f)$. These data show that DRG KAR composition is more complex than homomeric GluK1-containing receptors (Swanson and Heinemann, 1998). We propose that most DRG KARs are heteromeric SEM.
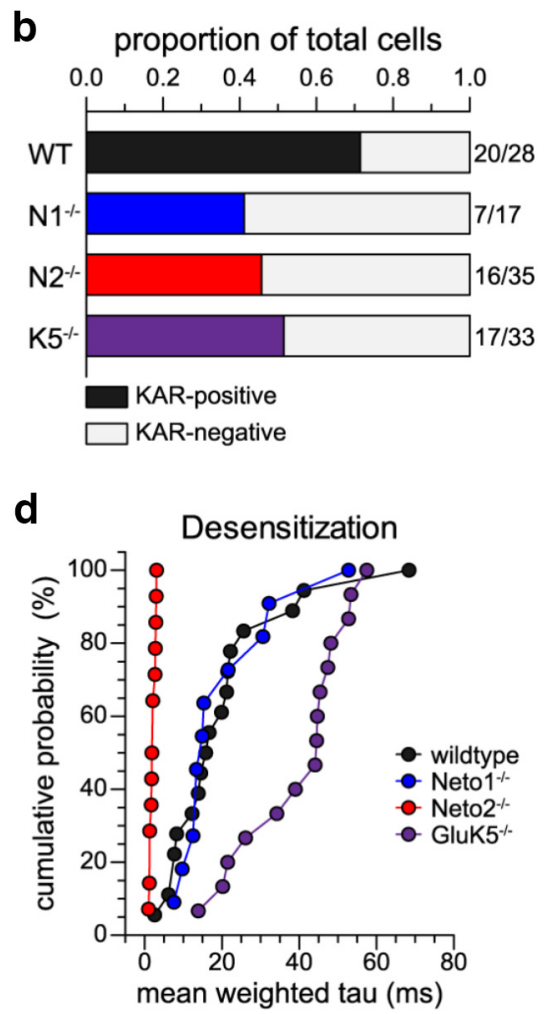

f

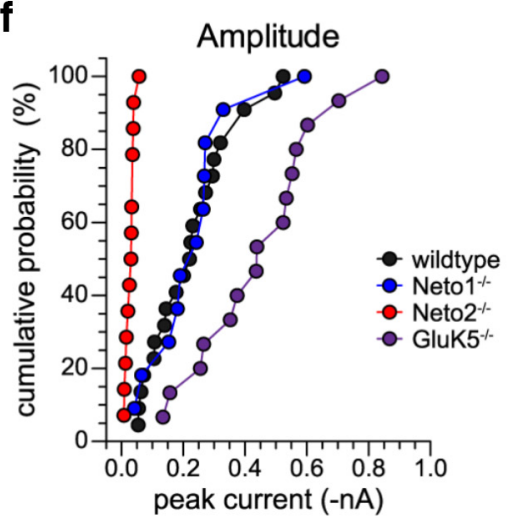

Figure 2. Net02 assembles into functional GluK1/GluK5-containing KARs in neonatal DRG neurons. $\boldsymbol{a}$, Representative current traces from wild-type (also presented in Fig. 1e), Net02 $2^{-1-}$, and GluK5 ${ }^{-1-}$ neonatal DRG neurons. Gray bar indicates glutamate $(10 \mathrm{~mm})$ application. $\boldsymbol{b}$, Proportion of small- and medium-diameter cells patched that expressed KAR-mediated current is represented in the filled bars. Empty bars are the proportion of KAR-negative cells patched for each genotype. c, Quantification of mean weighted tau of glutamate-evoked desensitization for wild-type, Neto $1^{-1-}$, Neto $2^{-1-}$, and GluK5 ${ }^{-1-}$ neonatal DRG neurons. $\boldsymbol{d}$, Cumulative probability histogram of individual cell desensitization rates for wild-type, Neto $1^{-1-}$, Neto2 $2^{-1-}$, and GluK5 ${ }^{-1-}$ neonatal DRG neurons. $e$, Quantification of peak glutamate-evoked current amplitude for wild-type, Neto $1^{-1-}$, Neto2 ${ }^{-1-}$, and $\mathrm{GluK5}^{-1-}$ neonatal DRG neurons. $\boldsymbol{f}$, Cumulative probability histogram of individual cell peak current amplitudes for wild-type, Neto1 ${ }^{-1-}$, Net02 $2^{-1-}$, and GluK5 ${ }^{-1-}$ neonatal DRG neurons. ${ }^{* *} p<0.01{ }^{* * *} p<0.001$. Error bars in column graphs indicate

GluK1/GluK5-containing receptors, that a variable proportion of KARs incorporate Neto2, and that Neto2 incorporation is a critical distinguishing factor between receptors in neonatal and adult neurons.

To test the hypothesis that Neto2 protein is upregulated with time in culture, we cultured wild-type DRG neurons for either 4 or $24 \mathrm{~h}$ before lysing the cells and probing for Neto 2 expression by Western blot. In agreement with our physiology data, we found that Neto2 expression in young cultures was high at early time points (Fig. 4a). Neto2 immunoreactivity from P5 cultures lysed at $4 \mathrm{~h}$ was $91 \pm 8 \%$ of P5 cultures lysed at $24 \mathrm{~h}$ (Fig. $4 b$ ). In contrast, Neto 2 immunoreactivity from P10 and P14 cultures 
a

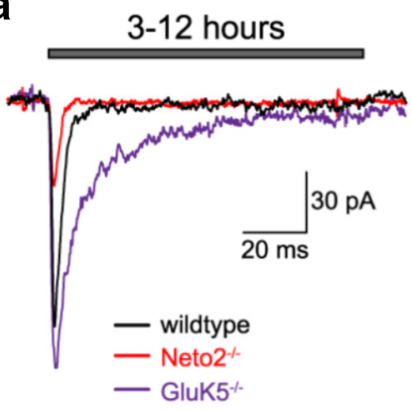

C

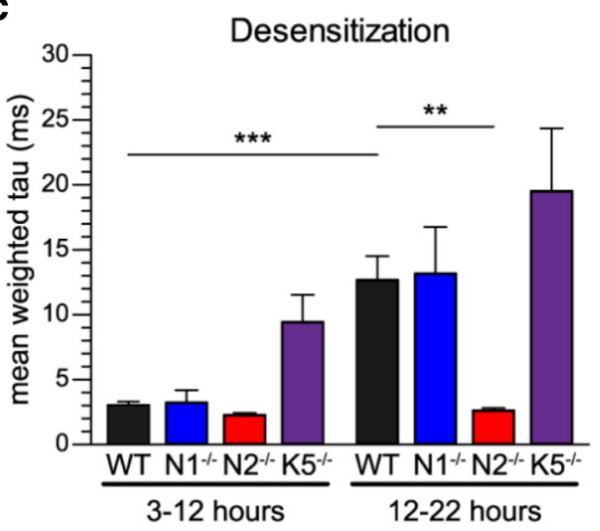

e

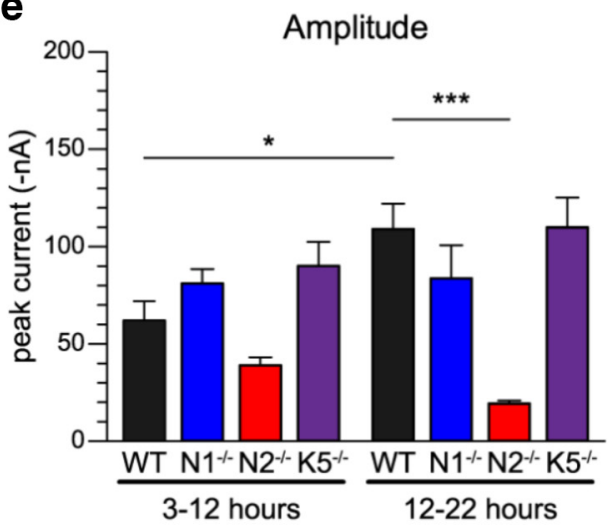

$12-22$ hours

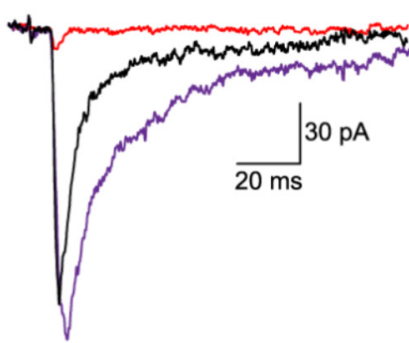

b

proportion of total cells

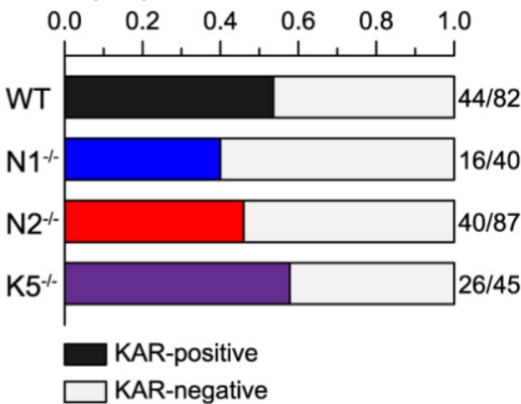

d

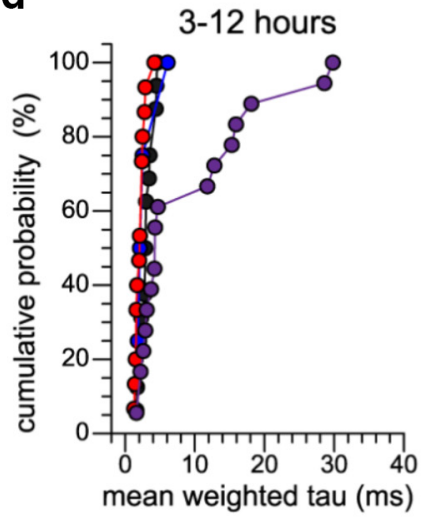

$\mathbf{f}$

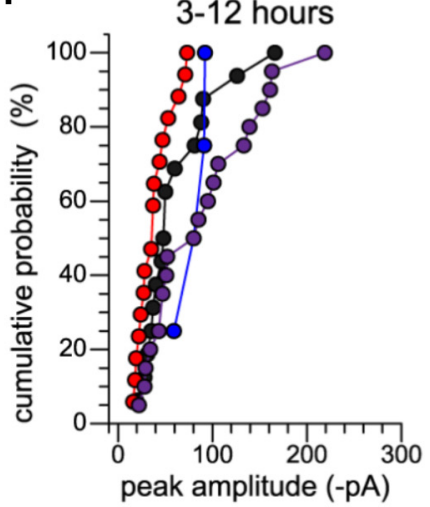

12-22 hours

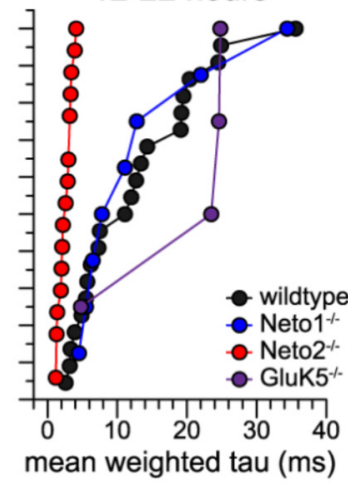

12-22 hours

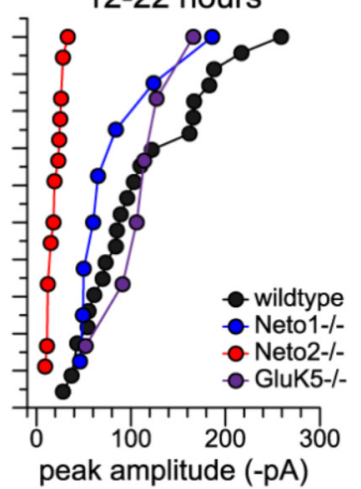

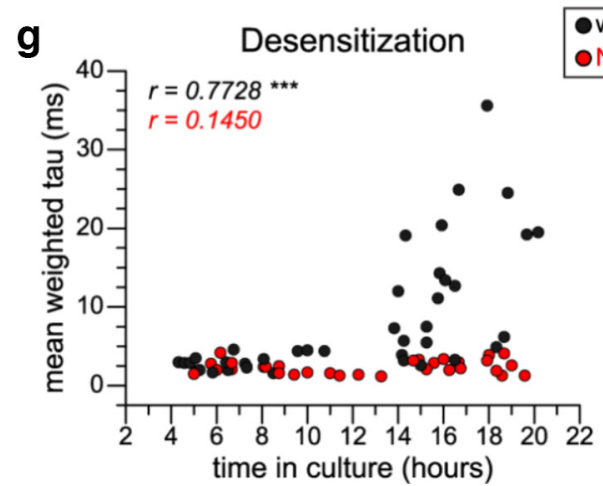

h Amplitude

wildtyp Neto $2^{--}$

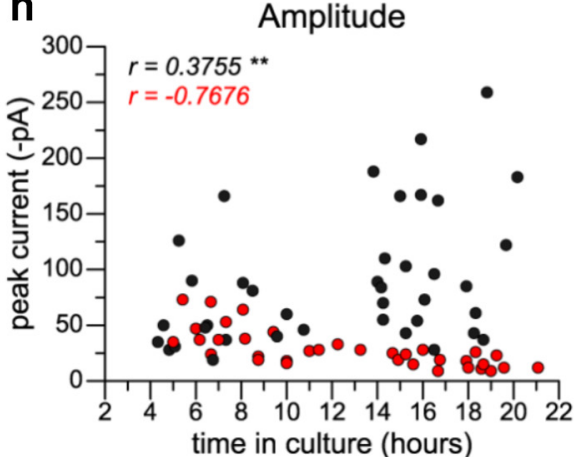

Figure 3. KARs in acutely plated adult DRG do not contain Net02 but increase Neto2 incorporation over time in culture. $\boldsymbol{a}$, Representative current traces from wild-type, Net02 ${ }^{-1-}$, and GluK5 ${ }^{-1-}$ adult DRG neurons are shown for both early and late recording time points: $3-12 \mathrm{~h}$ and $12-22 \mathrm{~h}$ in culture, respectively. $\boldsymbol{b}$, Proportion of small-and medium-diameter cells patched that expressed KAR-mediated current is represented in the filled bars. Empty bars are the proportion of KAR-negative cells patched for each genotype. c, Quantification of mean weighted tau of glutamate-evoked desensitization for wild-type, Neto $1^{-1-}$, Net02 ${ }^{-1-}$, and GluK5 ${ }^{-1-}$ adult DRG neurons. Data are grouped by whether the cell was recorded at 3-12 $\mathrm{h}$ or $12-22 \mathrm{~h}$ after the (Figure legend continues.) 
lysed at 4 h was only $67 \pm 26 \%$ and $24 \pm$ $12 \%$ of P5 cultures at $24 \mathrm{~h}$, respectively $(n=3 ; p=0.0169 ; \mathrm{P} 14$ at $4 \mathrm{~h}$ compared with $\mathrm{P} 5$ and $\mathrm{P} 14$ at $24 \mathrm{~h}, p<0.05$ ) (Fig. $4 b)$. Neto 2 expression at the early time point in P14 cultures was similar to that in adult DRG cultures, in which Neto2 immunoreactivity from cultures lysed at $4 \mathrm{~h}$ was only $28 \pm 5 \%$ of the Neto 2 signal from cultures lysed after $24 \mathrm{~h}(p<0.001$; Fig. $4 c, d)$. Furthermore, this upregulation of Neto2 in culture depended on intact ERK1/2 signaling because inhibition of ERK phosphorylation by $50 \mu \mathrm{M} \mathrm{U} 0126$ maintained Neto 2 expression at $38 \pm 7 \%$ of control cultures at $24 \mathrm{~h}(p<0.001$ compared with untreated cultures at $24 \mathrm{~h}$; Fig. $4 c, d)$. Phosphorylated ERK1/2 is transported from the site of axonal injury to the nucleus in DRG neurons and is a critical early component of the cellular program mobilized for process regeneration in sensory neurons (Perlson et al., 2005). Acutely isolated DRG neurons underwent exuberant axon regrowth during the $24 \mathrm{~h}$ in which we observed Neto2 upregulation. We therefore tested the contribution of other signaling molecules implicated in axon outgrowth, PI3K (Saijilafu et al., 2013) and its downstream effector Akt, to Neto2 upregulation in the adult DRG cultures. Neto2 upregulation was unaffected by the PI3K inhibitor wortmannin $(10 \mathrm{nM}, 102 \pm 6 \%$ of control immunoreactivity; $p>0.05$ vs untreated cultures at $24 \mathrm{~h}$ ), but was significantly reduced by the Akt inhibitor triciribine $(20 \mu \mathrm{M})$, which reduced Neto 2 immunoreactivity to $63 \pm 10 \%$ of control $(p<0.05$ vs untreated cultures at $24 \mathrm{~h}$ ) (Fig. $4 a, b)$. It seems, therefore that Neto2 upregulation is supported by multiple kinases, but is not a general component of growth-permissive signaling pathways.

KARs in DRG neurons have been implicated in multiple functional roles as peripheral chemosensors (Carlton et al., 1995), presynaptic autoreceptors in the spinal cord (Kerchner et al., 2001b; Kerchner et al., 2002), and trophic stimulators of axon outgrowth (Joseph et al., 2011; Marques et al., 2013). Pharmacological inhibition or genetic ablation of GluK1-containing KARs also reduces some forms of inflammatory or neuropathic pain (Simmons et al., 1998; Qiu et al., 2011). We tested the role of Neto2 in mediating persistent pain modalities and neurite outgrowth in

\footnotetext{
(Figure legend continued.) cultures were plated. $\boldsymbol{d}$, Cumulative probability histogram of individual cell desensitization rates for wild-type, Neto $1^{-I-}, \mathrm{Net}_{0} 2^{-I-}$, and GluK5 ${ }^{-I-}$ adult DRG neurons. $\boldsymbol{e}$, Quantification of peak glutamate-evoked current amplitudes for wild-type, Neto $1^{-I-}$, Neto $2^{-I-}$, and GluK5 ${ }^{-/-}$adult DRG neurons. Data are grouped by whether the cell was recorded $3-12 \mathrm{~h}$ or $12-22 \mathrm{~h}$ after the cultures were plated. $f$, Cumulative probability histogram of individual cell peak current amplitudes for wild-type, $\mathrm{Net}^{-1}{ }^{-1-}, \mathrm{NetO}^{-1-}$, and GluK5 ${ }^{-1-}$ adult DRG neurons. $\boldsymbol{g}$, Wild-type and Neto $2^{-/-}$data from $\boldsymbol{d}$ represented as desensitization rate versus time-in-culture to demonstrate visually the correlations reported in the text. $\boldsymbol{h}$, Wild-type and Neto $2^{-1-}$ data from $\boldsymbol{e}$ represented as peak current amplitude versus time-in-culture to demonstrate visually the correlations reported in the text. ${ }^{* * *} p<0.001$. Error bars in column graphs indicate SEM.
}
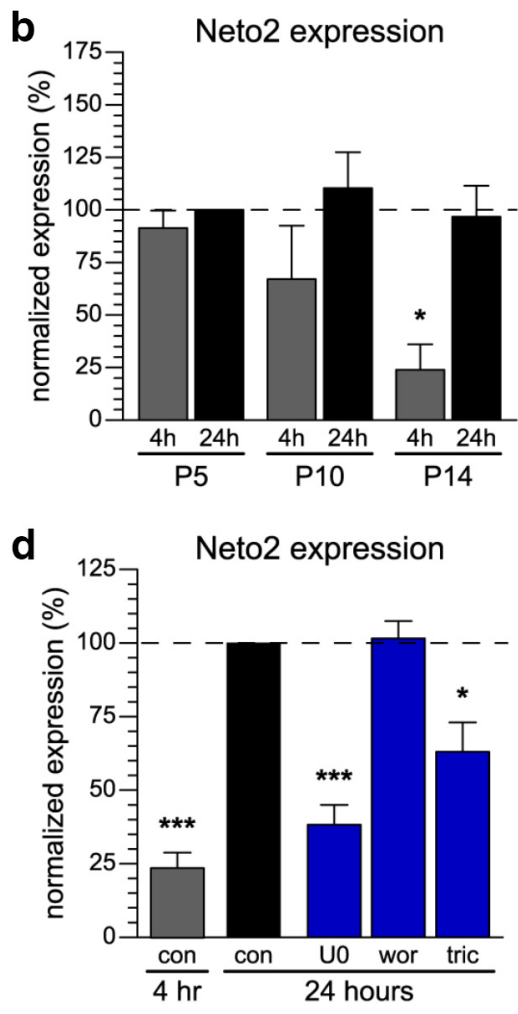

Figure 4. Neto2 is upregulated in older DRG cultures and ERK activation is required for Neto 2 upregulation in adult DRG neurons $\boldsymbol{a}$, Representative Western blot of Net0 2 expression in young wild-type DRG cultures at 4 and $24 \mathrm{~h}$. $\boldsymbol{b}$, Densitometry quantification EM. ${ }^{*} p<0.05 ;{ }^{* * *} p<0.001$. con, Untreated control cultures; U0, cultures treated with U0126; wor, cultures treated with wortmannin; tric, cultures treated with triciribine.

cultured adult DRG neurons. First, we evaluated baseline and short-term pain behaviors in Neto $1^{-1-}$ and Neto $2^{-1-}$ mice, an experiment that had the additional use of evaluating a known GluK1-dependent behavioral phenotype in KAR auxiliary subunit knock-out mice, the behavior of which has been minimally characterized to date (Ng et al., 2009; Mahadevan et al., 2015). Given that GluK1-containing KARs are not involved in acute pain signaling (Sang et al., 1998; Qiu et al., 2011), we expected basal pain thresholds to be intact in the absence of Neto proteins. Neto $1^{-1-}$ mice showed withdrawal latencies from a calibrated heat source of $6.7 \pm 0.4 \mathrm{~s}(n=33)$, which were indistinguishable from the $7.0 \pm 0.4 \mathrm{~s}$ latencies $(n=31)$ of their wild-type littermates $(p=0.5726)$; Neto $2^{-l-}$ mice also withdrew from the heat source similar to their wild-type littermates with latencies of $5.2 \pm 0.3 \mathrm{~s}(n=36)$ and $5.8 \pm 0.2 \mathrm{~s}(n=42)$, respectively $(p=$ 0.0825 ; data not shown). Like thermal sensitivity, mechanical sensitivity was unchanged by genetic ablation of Neto proteins. Wild-type and $\mathrm{Neto}^{-1-}$ littermates responded at $0.72 \pm 0.06 \mathrm{~g}$ $(n=30)$ and $0.80 \pm 0.07 \mathrm{~g}(n=27)$, respectively $(p=0.3962)$, and Neto $2^{-1-}$ animals $(n=25)$ and their wild-type littermates $(n=21)$ had indistinguishable mechanical thresholds of $0.61 \pm$ $0.05 \mathrm{~g}$ and $0.67 \pm 0.06 \mathrm{~g}(p=0.429)$.

Although our data (Figs. 1, 3) suggest that Neto2 in adult peripheral neurons would not contribute to immediate inflammatory pain behaviors, it was possible that KARs elsewhere in the pain neuraxis would be compromised by loss of an auxiliary subunit and that this would result in a deficit in spontaneous 


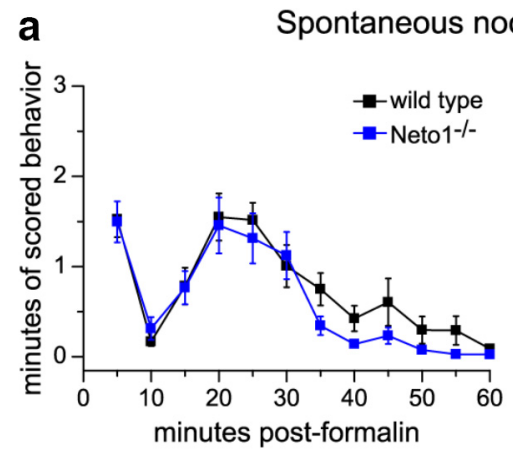

Spontaneous nocifensive behavior

\section{b}

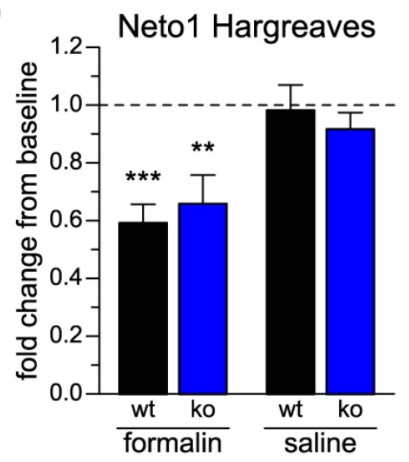

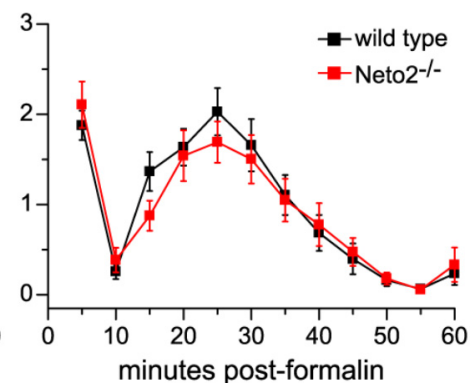

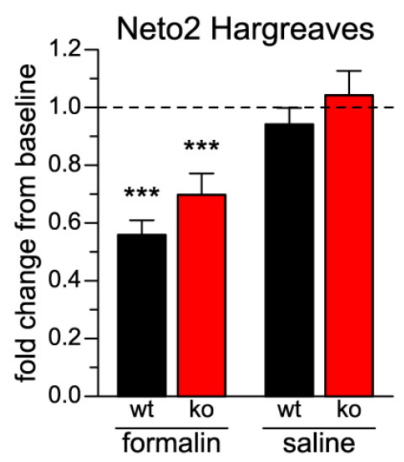

Figure 5. Neto ${ }^{-1-}$ mice show normal formalin pain behaviors and normal formalin-induced inflammatory heat hypersensitivity. $\boldsymbol{a}$, Neto $1^{-1-}$ and Neto $2^{-1-}$ mouse spontaneous pain behavior after formalin injection compared with their wild-type littermates. Measured time spent on nocifensive behaviors was pooled into $5 \mathrm{~min}$ bins. Saline-injected animals did not show nocifensive behaviors over the $60 \mathrm{~min}$ after injection and these data are omitted from graphs for the purpose of clarity. $\boldsymbol{b}$, Neto $1^{-1-}$ and Net02 $2^{-1-}$ mouse thermal hypersensitivity compared with their wild-type littermates. Hypersensitivity was measured by Hargreaves test $3 \mathrm{~h}$ after formalin injection and is represented as the fold change from the withdrawal latency measured before formalin injection. Error bars indicate SEM. ${ }^{*} p<0.05 ;{ }^{* * *} p<0.001$.

formalin behaviors like that seen in the GluK1 $1^{-1-}$ mouse (Ko et al., 2005). We found, however, that $\mathrm{Netol}^{-1-}(n=20)$ and Neto $2^{-1-}$ mice $(n=22)$ exhibited the same two-phase spontaneous pain behaviors as their respective wild-type littermates $\left(n=18 \mathrm{Neto}^{+/+}\right.$and $n=25 \mathrm{Neto}^{+/+}$animals), with genotype not altering the time course of either curve (two-way repeatedmeasures ANOVA, Netol comparison $p=0.0554$, Neto 2 comparison $p=0.5974$ ) (Fig. 5a). In addition, it was possible that inflammation would upregulate Neto2 in DRG neurons in a manner similar to what we saw in cultures and that we would observe a Neto2-dependent deficit in inflammatory hypersensitivity. To test this idea, we retested the latency to withdrawal from heat $3 \mathrm{~h}$ after either formalin or saline injection. Saline-injected mice showed unchanged heat sensitivity in both the Neto1 $(0.98 \pm 0.09$ and $0.92 \pm 0.06$ fold-change from baseline for $\mathrm{Netol}^{+/+}$and $\mathrm{Neto}^{-/-}$, respectively; $n=13$ for both groups, one-sample $t$ test $p=0.8388$ and 0.1733$)$ and Neto2 strains $(0.94 \pm 0.06(n=18)$ and $1.04 \pm 0.09(n=14)$ fold-change was observed for Neto2 $2^{+/+}$and Neto $2^{-/-}$mice, $p=0.3198$ and $0.6354)$ (Fig. 5b). Formalin-inflamed Neto1 $1^{-1-}$ mice $(n=20)$ developed hypersensitivity that reduced their heat tolerance to $0.66 \pm 0.10$-fold of their baseline withdrawal latency $(p=$ $0.0029)$, similar to $0.59 \pm 0.07$-fold heat tolerance seen in their formalin-injected wild-type littermates $(n=18, p<0.0001)$ (Fig. $5 b)$. The same normal hypersensitivity developed in both genotypes of Neto2 animals, in which heat tolerance was reduced to $0.56 \pm 0.05$-fold of baseline in wild-type littermates $(n=25, p<$ 0.0001 ) and to $0.70 \pm 0.07$-fold of baseline thresholds in
Neto $2^{-1-}$ mice $(n=22, p=0.0006)$ (Fig. $5 b$ ). Therefore, these knock-out mice have intact short-term hypersensitivity.

KARs are known to modulate axon outgrowth in cultured DRG neurons from early developmental stages and the Neto2 upregulation that we observed in adult neuron cultures coincides with a period of rapid axon regeneration that, like Neto2 upregulation, is stunted by ERK1/2 inhibition. In addition, our recordings from neurons that had not yet grown neurites (Fig. 3) suggest that Neto2 upregulation begins before axonal outgrowth. To determine whether upregulation of Neto2-containing KARs modulated neurite outgrowth in our adult cultures, we electroporated neurons from wild-type and $\mathrm{Neto}^{-1-}$ mice with eGFP and fixed them $24 \mathrm{~h}$ after plating. At this time in culture, neurons are still maturing and show multiple stages of outgrowth (Smith and Skene, 1997; Marques et al., 2013). Neuronal axon arbors were imaged and traced to quantify outgrowth; experiments and analysis were performed blinded to genotype. To compare neurons at similar growth stages, we divided neurons into three groups based on the size and complexity of their axon arbors: immature (Stage 1), intermediate (Stage 2), and mature/elongating (Stage 3) (Marques et al., 2013; see Materials and Methods for details; see Fig. $6 a$ for example images). Twentyfour hours after plating, 51\% of wild-type neurons had reached the intermediate growth stage with highly ramified arbors, $16 \%$ had fully matured and reached elongating growth, and only $33 \%$ remained in early stages of growth. In contrast, $42 \%$ of Neto ${ }^{-1-}$ neurons remained in the early growth stage and smaller proportions of $46 \%$ and $12 \%$ reached intermediate and mature/elongating growth, respectively (Fig. 6b). In wild-type neurons, the length of the longest neurite on each cell increased significantly from $30 \pm 8 \mu \mathrm{m}$ in Stage 1 neurons $(n=22)$ to $266 \pm 14 \mu \mathrm{m}$ in Stage $2(n=34)$ and $462 \pm 60 \mu \mathrm{m}$ in Stage 3 neurons $(n=11)$ (ANOVA $p<0.0001, p<0.001$ for all comparisons) (Fig. $6 c$ ). We found that $\mathrm{Neto}^{-1-}$ neurons also showed an increase in longest neurite length between Stage 1 and Stage 2 ( $37 \pm 10 \mu \mathrm{m}, n=17$, and $232 \pm 16 \mu \mathrm{m}, n=19$, respectively; $p<0.001)$. However, neurites on Stage 3 neurons from Neto $2^{-/-}$ mice elongated to only $241 \pm 25 \mu \mathrm{m}(n=5)$, a length that was not longer than the Stage $2 \mathrm{Neto}^{-1-}$ neurites $(p>0.05)$ and significantly shorter than the longest axons measured on Stage 3 wild-type neurons $(p<0.001)$ (Fig. $6 c)$. At each stage, we observed no difference between wild-type and Neto $2^{-1-}$ neuron branch number (Stage 1: $7 \pm 3$ and $6 \pm 2$; Stage 2: $231 \pm 20$ and $244 \pm 32$; Stage 3: $34 \pm 6$ and $36 \pm 10 ; p>0.05$ for all within-stage comparisons) (Fig. 6d).

To further characterize neurite outgrowth in these cultures, we performed Sholl analysis on the traced neurite arbors, quantifying the total number of neurite crossings at $5 \mu \mathrm{m}$ increasing intervals from the soma. Both Stage 2 and Stage 3 neurons from Neto $2^{-1-}$ cultures showed significantly reduced arbor complexity compared with wild-type neurons of the same stage (two-way ANOVA, $p<0.0001$ for genotype as a source of variation at both 


\section{a}

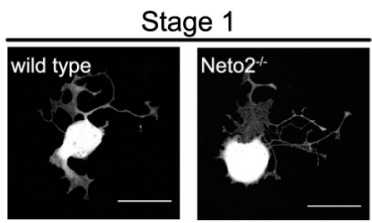

Stage 2
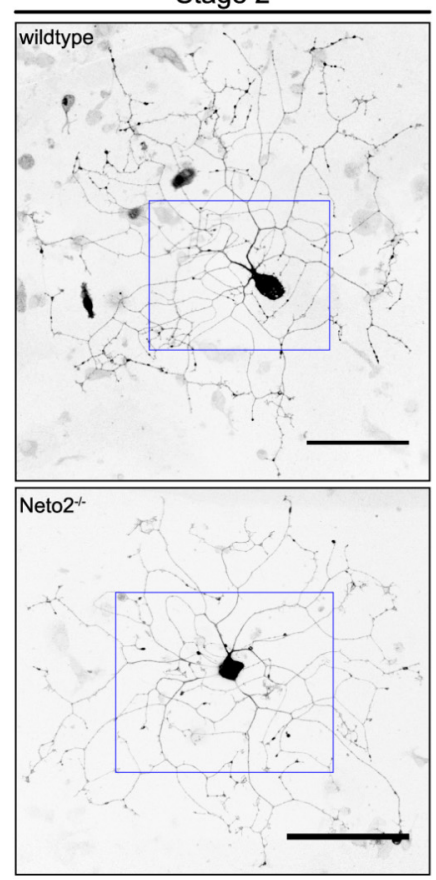

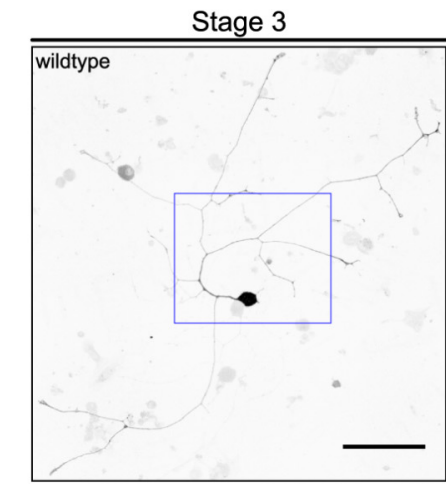

Neto2--
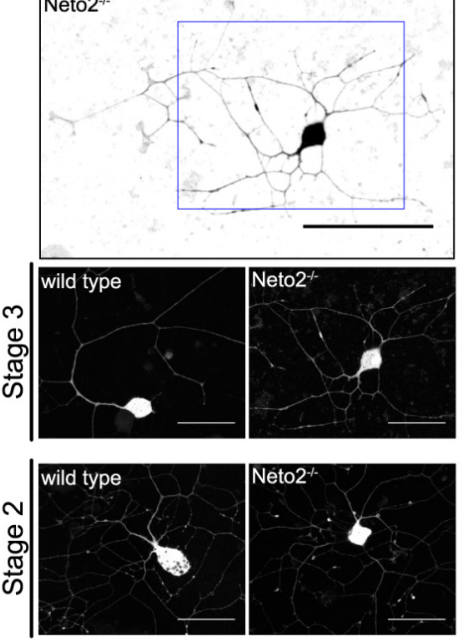

b

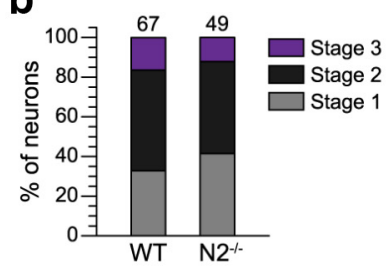

C Longest Neurite

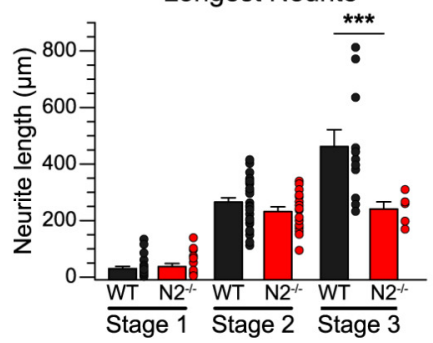

d

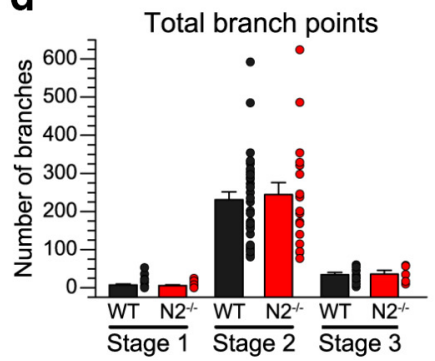

e

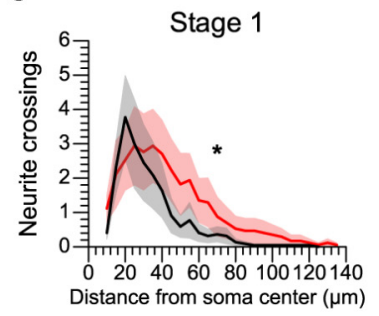

Stage 2

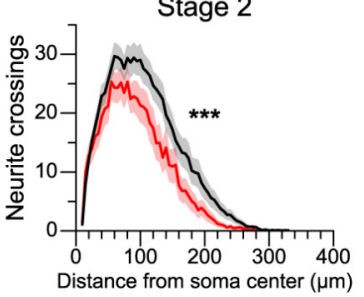

Stage 3

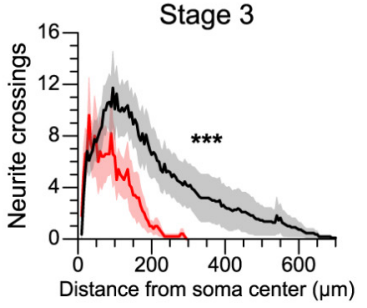

Figure 6. Neto $2^{-1-}$ DRG neurons from adult mice show stunted neurite outgrowth and maturation in culture compared with wild-type neurons. $a$, Representative images of wild-type and Net $02^{-1-}$ neurons from each maturation stage. Stage 2 and 3 inverted images show the full axon arbor for each cell and the area within the blue boxes is magnified to demonstrate branching. Black scale bars, $100 \mu \mathrm{m}$; white scale bars, $50 \mu \mathrm{m}$. $\boldsymbol{b}$, Percentage of wild-type and Neto $2^{-1-}$ cells at each maturation stage (see Materials and Methods for details). $\boldsymbol{c}$, Length of the longest neurite measured from each cell in wild-type and Neto $2^{-1-}$ adult neurons. Cells were electroporated with eGFP and fixed after $24 \mathrm{~h}$ in culture. Data are grouped by the cell's maturation stage. $\boldsymbol{d}$, Number of branch points measured on each cell in wild-type and Net02 $2^{-1-}$ adult neurons. Data are grouped by the cell's maturation stage. $e$, Sholl analysis was performed on axon arbor tracings of wild-type and Neto $2^{-1-}$ adult neurons at $5 \mu \mathrm{m}$ intervals from the soma center. Sholl data are grouped by maturation stage for presentation and analysis. Error bars on column graphs indicate SEM. ${ }^{*} p<0.05 ;{ }^{* *} p<0.01 ;{ }^{* * *} p<0.001$.

Stage 2 and Stage 3; Fig. 6e). Interestingly, Sholl analysis of Stage 1 neurons showed increased complexity in Neto $2^{-1-}$ neurons compared with their wild-type counterparts $(p=0.0123$ for genotype as a source of variation; Fig. 6e), suggesting that the contribution of Neto2-containing receptors early in neurite outgrowth might differ from their role in later stages of growth.

The peripheral branch of DRG axons retains the capacity for regeneration in the adult. Crush injury to the sciatic nerve induces regrowth of axons through the site of injury and recovery of motor control and sensation in the distal toes within $\sim 10$ weeks in mouse (Decosterd et al., 2002). To determine whether Neto2 might be upregulated in this in vivo regeneration, as would be predicted from our results in cultured neurons, we performed nerve crush injury on wild-type mice and then tested Neto 2 protein levels in DRG and sciatic nerve by Western blot 3, 7, and $10 \mathrm{~d}$ after surgery (Fig. 7a). We found that Neto2 protein expression ipsilateral to the crush injury increased to twice that of sham after $7 \mathrm{~d}(p=0.0467$, repeated-measures ANOVA, $n=3, p<0.05 \mathrm{~d} 7$ ipsilateral crush vs sham) and $10 \mathrm{~d}(p=0.0538, p<0.05 \mathrm{~d} 10$ ipsilateral crush vs sham) (Fig. $7 b$ ). Neto2 expression was not different between crushed and sham tissue $3 \mathrm{~d}$ after nerve crush injury ( $p=0.6626$ ) (Fig. $7 b$ ). Therefore, Neto 2 protein is upregulated in an injury model that induces axon outgrowth from sensory ganglia neurons.

\section{Discussion}

We report here that Neto2 is a bona fide KAR auxiliary subunit because it assembles with KARs and affects their functional properties in DRG neurons. Moreover, we find a substantial difference in the composition of neonatal and adult KARs that primarily results from developmental downregulation of Neto2. Finally, our data suggest that Neto2-containing KARs contribute to regulated process outgrowth from sensory neurons rather than mediating inflammatory pain states.

KARs in DRG neurons contain the GluK1 subunit as an essential constituent (Mulle et al., 2000; Kerchner et al., 2002; Rozas et al., 2003), but the extent to which other subunits contribute to KAR signaling is less clear. GluK1, GluK5, and Neto2 mRNAs are detected in DRG (Bettler et al., 1990; Herb et al., 1992; Partin et al., 1993; Allen Institute for Brain Science, 2015). Here, we show that Neto2 shapes KAR currents evoked from DRG neurons in a manner consistent with its effects on recombinant KARs (Zhang et al., 2009; Copits et al., 2011; Straub et al., 2011a) and neuronal KARs (Palacios-Filardo et al., 2016). KAR currents desensitize at different rates depending on the subunit composition of the receptors, with GluK5 incorporation speeding desensitization of recombinant GluK1-containing receptors (Swanson et al., 1998) and Neto2 incorporation slowing desensitization of GluK1- 
a

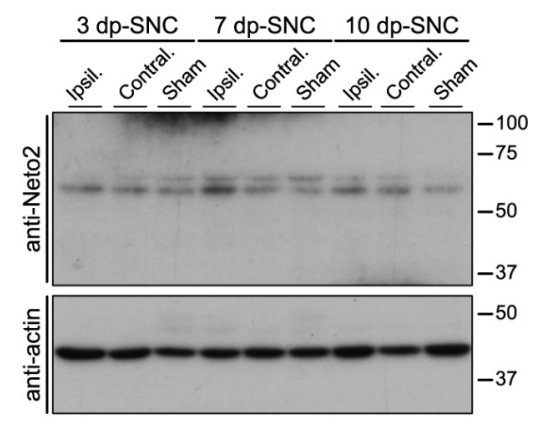

b

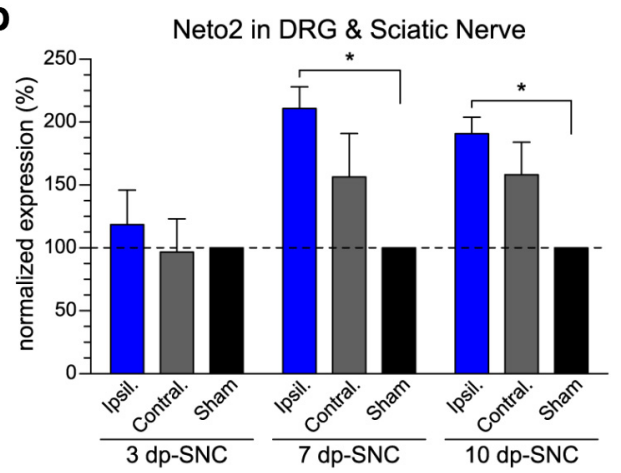

Figure 7. Sciatic nerve crush upregulates Neto2 in vivo. $\boldsymbol{a}$, Representative Western blot showing Neto2 and actin expression in homogenized DRG and sciatic nerve tissue taken 3, 7, or $10 \mathrm{~d}$ post-sciatic nerve crush (dp-SNC). Tissue was taken ipsilateral to the crushed nerve (Ipsil.), contralateral to the crushed nerve (Contral.), or ipsilateral to an exposed surgical sham nerve (Sham). $\boldsymbol{b}$, Densitometry quantification of Neto2 normalized to actin. Within each time point, Neto2 expression in Sham tissue was set to $100 \%$. Error bars indicate SEM. ${ }^{*} p<0.05$.

containing and GluK1/GluK5-containing receptors (Copits et al., 2011; Straub et al., 2011a). We found that genetic deletion of Neto2 makes KAR currents in neonatal neurons desensitize more rapidly, whereas elimination of GluK5 has the opposite effect, suggesting that these neurons express predominantly GluK1/ GluK5/Neto2-containing KARs. DRG KAR desensitization is slower than for recombinant GluK1/GluK5/Neto2-containing receptors, however, which could reflect the mixed composition of receptors on the cell surface or might be due to an additional component of native receptors that has yet to be recapitulated in recombinant systems. Regardless, our data confirm that Neto2 is a component of endogenous KARs in sensory neurons.

KAR composition and function have not been studied in adult DRG neurons. We found that neonatal Neto2 expression was downregulated by P14 and adult KAR currents differ strikingly from neonatal currents in a Neto2-dependent manner. Distinct KAR subunit composition between adult and neonatal neurons is intriguing given that GluK1-containing KARs in DRG are expressed specifically in nociceptors, are involved in persistent but not acute pain in adult animals, and modulate neonatal DRG neurite outgrowth. It is possible that KAR function in sensory neurons is altered over the rodent lifetime as the receptor subunit composition changes.

The expression of KARs in peripheral nociceptors is relevant to understanding their contribution to pathological pain. GluK $1^{-1-}$ mice have reduced formalin-induced pain behaviors (Ko et al., 2005) and GluK1-directed functional antagonists alleviate hypersensitive pain in rodents (Simmons et al., 1998; Dominguez et al., 2005; Qiu et al., 2011). In addition, a GluK1 antagonist alleviated inflammatory thermal hypersensitivity and migraine pain in people (Sang et al., 1998; Sang et al., 2004). It remains unclear precisely where in the pain neuraxis GluK1containing KAR signaling supports these pathologic pain states, however, because GluK1-containing KARs are expressed in central pain centers and modulate various functions related to circuit excitability and pain behaviors (Kerchner et al., 2001a; Kerchner et al., 2002; Binns et al., 2003; Palecek et al., 2004; Wu et al., 2007; Nakamura et al., 2010; Descalzi et al., 2013; Koga et al., 2015). We find that $\mathrm{Neto}^{-/-}$and Neto $2^{-/-}$mice have normal acute thermal and mechanical pain thresholds, an expected finding given that KARs do not affect acute pain signaling (Sang et al., 1998; Qiu et al., 2011). Our behavioral data also show that Neto proteins do not contribute to short-term inflammatory pain, consistent with the absence of Neto-containing KARs in adult sensory neurons. The delayed Neto 2 upregulation that we observed after sciatic nerve crush suggests that it will be important to determine whether KAR contributions to long-term persistent pain engage or are independent of Neto proteins.

KARs modulate neurite outgrowth from peripheral sensory neurons. In embryonic cultures, the agonist kainate inhibited outgrowth, whereas KAR antagonists promoted elongation (Joseph et al., 2011). Further, KARs modulated early and elongating outgrowth bidirectionally and the rate at which neonatal neurons progressed through outgrowth stages (Marques et al., 2013). The high Neto2 expression in neonatal DRG neurons suggests it is a component of the KAR signaling complex modulating axon outgrowth. Our finding that Neto2 expression is low in adult DRG is consistent with the static growth state of these neurons and the culture results suggest that axon regeneration engages Neto2-containing KARs. We observed aberrant Neto $2^{-1-}$ arbor complexity at both early and later growth stages. Most of these alterations are consistent with the previously reported effect of high kainate concentrations on young wild-type cultures: reduced elongating outgrowth and reduced intermediate and elongating arbor complexity (Joseph et al., 2011; Marques et al., 2013).

A change in KAR signaling is the most straightforward explanation of the altered outgrowth that we saw in Neto $2^{-1-}$ neurons, given the previous evidence that these receptors play a role in this process (Joseph et al., 2011; Marques et al., 2013). However, other mechanisms that we cannot rule out include compensatory responses to genetic deletion of Neto2 or interactions between Neto 2 and non-KAR signaling systems that change the process of axon regeneration. With respect to compensation, Neto $2^{-/-}$mice show normal expression of kainate, AMPA, and NMDA receptor subunits in the hippocampus (Tang et al., 2011; Tang et al., 2012) and no evidence exists for functional replacement of the auxiliary protein in KAR currents (Straub et al., 2011b; Tang et al., 2011; Wyeth et al., 2014). Neto2 does interact with and modulate the function of the chloride transporter KCC2 and KCC2 protein is reduced in Neto $2^{-1-}$ hippocampus (Ivakine et al., 2013; Mahadevan et al., 2014). This interaction is unlikely to be relevant to our outgrowth data because DRG neuron intracellular chloride levels are controlled primarily by NKCC1 and KCC3 rather than the KCC2 isoform (Sung et al., 2000; Lucas et al., 2012; Mao et al., 2012). Therefore, the weight of evidence supports our working hypothesis that Neto2 plays a role in axon outgrowth as a result of assembly into KARs and consequent modification of their functional properties.

Altered outgrowth in adult Neto2 $2^{-/-}$DRG cultures is consistent with our finding that Neto 2 upregulation in adult neurons depended on activation of the positive regenerative injury signal pERK. Transportation of $\mathrm{pERK} 1 / 2$ from the axonal site of injury 
to the nucleus is critical to neurite regrowth and the outgrowthpriming effect of peripheral nerve injury (Perlson et al., 2005). We found that inhibition of MEK/ERK signaling blocked Neto2 upregulation in adult DRG cultures. Akt is the major effector of PI3K, another kinase that promotes neurite regrowth (Saijilafu et al., 2013), yet Akt-mediated signaling partially contributes to Neto2 upregulation whereas PI3K-mediated signaling does not. It is becoming evident that a number of kinases can activate Akt independently of PI3K (Mahajan and Mahajan, 2012) and, of these, the Src family of kinases has known functions in DRG that include transducing growth-supportive signaling (Tucker et al., 2008). It will be informative to determine whether the signaling cascades that control Neto2 expression during regeneration also regulate KAR subunits during innervation of the spinal cord during development.

The observation that Neto2 increased after sciatic nerve crush confirms that its expression in adult neurons is malleable under pathological conditions. Whether nerve injury induces a general upregulation of all KAR subunits or a selective increase of Neto2 remains to be determined. Nerve crush injury induces a broad array of changes in peripheral neurons as distal axons degenerate and neurons switch from a signal-conducting expression profile to a regenerative expression profile (Navarro et al., 2007). Neto2 expression peaks $\sim 1$ week after injury, following a slower time course than was observed in our cultures. Although peripheral axons can sprout growth cones and begin regenerating within the first day after injury, the majority of axons initiate growth more slowly, with fewer than half reaching $3 \mathrm{~mm}$ past the proximal site of injury after $5 \mathrm{~d}$ (Pan et al., 2003). A regenerative lag period exists during the first $3 \mathrm{~d}$ after nerve crush (Danielsen et al., 1986; Pan et al., 2003; Sta et al., 2014); the lack of Neto2 upregulation at $3 \mathrm{~d}$ after nerve crush therefore suggests that KARs containing Neto2 are not involved in initial growth cone sprouting, but rather in established regrowth, an interpretation that is consistent with our culture outgrowth data. It will be important to determine what effect loss of Neto2 from KARs has on regenerating peripheral axons. Our culture experiments suggest that the initial growth sprouting could be more robust, but that elongating regrowth would ultimately be stunted in Neto $2^{-I-}$ mice, potentially affecting the rate or extent of functional recovery.

In conclusion, we demonstrate that Neto2 is a bona fide auxiliary subunit that is a developmentally downregulated but dynamic component of KARs that regulates sensory axon regrowth in nociceptors. These findings raise the possibility of differential KAR functions in neonatal and adult nociceptors. This information is critical to improving our mechanistic understanding of neural circuit modulation by KARs and the contributions of KAR-mediated signaling to normal development and disease states.

\section{References}

Agrawal SG, Evans RH (1986) The primary afferent depolarizing action of kainate in the rat. Br J Pharmacol 87:345-355. CrossRef Medline

Allen Institute for Brain Science (2015) Allen Spinal Cord Atlas. [Internet]. Available from: http://mousespinal.brain-map.org. Accessed: November $1,2013$.

Bettler B, Boulter J, Hermans-Borgmeyer I, O'Shea-Greenfield A, Deneris ES, Moll C, Borgmeyer U, Hollmann M, Heinemann S (1990) Cloning of a novel glutamate receptor subunit, GluR5: expression in the nervous system during development. Neuron 5:583-595. CrossRef Medline

Bhangoo SK, Swanson GT (2013) Kainate receptor signaling in pain pathways. Mol Pharmacol 83:307-315. CrossRef Medline

Binns KE, Turner JP, Salt TE (2003) Kainate receptor (GluR5)-mediated disinhibition of responses in rat ventrobasal thalamus allows a novel sensory processing mechanism. J Physiol 551:525-537. CrossRef Medline

Carlton SM, Hargett GL, Coggeshall RE (1995) Localization and activation of glutamate receptors in unmyelinated axons of rat glabrous skin. Neurosci Lett 197:25-28. CrossRef Medline

Contractor A, Sailer AW, Darstein M, Maron C, Xu J, Swanson GT, Heinemann SF (2003) Loss of kainate receptor-mediated heterosynaptic facilitation of mossy-fiber synapses in KA2-/- mice. J Neurosci 23:422-429. Medline

Contractor A, Mulle C, Swanson GT (2011) Kainate receptors coming of age: milestones of two decades of research. Trends Neurosci 34:154-163. CrossRef Medline

Copits BA, Robbins JS, Frausto S, Swanson GT (2011) Synaptic targeting and functional modulation of GluK1 kainate receptors by the auxiliary neuropilin and tolloid-like (NETO) proteins. J Neurosci 31:7334-7340. CrossRef Medline

Copits BA, Vernon CG, Sakai R, Swanson GT (2014) Modulation of ionotropic glutamate receptor function by vertebrate galectins. J Physiol 592: 2079-2096. CrossRef Medline

Danielsen N, Lundborg G, Frizell M (1986) Nerve repair and axonal transport: outgrowth delay and regeneration rate after transection and repair of rabbit hypoglossal nerve. Brain Res 376:125-132. CrossRef Medline

Decosterd I, Allchorne A, Woolf CJ (2002) Progressive tactile hypersensitivity after a peripheral nerve crush: non-noxious mechanical stimulusinduced neuropathic pain. Pain 100:155-162. CrossRef Medline

Descalzi G, Chen T, Koga K, Li XY, Yamada K, Zhuo M (2013) Cortical GluK1 kainate receptors modulate scratching in adult mice. J Neurochem 126:636-650. CrossRef Medline

Dominguez E, et al. (2005) Two prodrugs of potent and selective GluR5 kainate receptor antagonists actives in three animal models of pain. J Med Chem 48:4200-4203. CrossRef Medline

Du J, Zhou S, Carlton SM (2006) Kainate-induced excitation and sensitization of nociceptors in normal and inflamed rat glabrous skin. Neuroscience 137:999-1013. CrossRef Medline

Herb A, Burnashev N, Werner P, Sakmann B, Wisden W, Seeburg PH (1992) The KA-2 subunit of excitatory amino acid receptors shows widespread expression in brain and forms ion channels with distantly related subunits. Neuron 8:775-785. CrossRef Medline

Huettner JE (1990) Glutamate receptor channels in rat DRG neurons: activation by kainate and quisqualate and blockade of desensitization by Con A. Neuron 5:255-266. CrossRef Medline

Ivakine EA, Acton BA, Mahadevan V, Ormond J, Tang M, Pressey JC, Huang MY, Ng D, Delpire E, Salter MW, Woodin MA, McInnes RR (2013) Neto2 is a KCC2 interacting protein required for neuronal Cl-regulation in hippocampal neurons. Proc Natl Acad Sci U S A 110:3561-3566. CrossRef Medline

Joseph DJ, Williams DJ, MacDermott AB (2011) Modulation of neurite outgrowth by activation of calcium-permeable kainate receptors expressed by rat nociceptive-like dorsal root ganglion neurons. Dev Neurobiol 71:818-835. CrossRef Medline

Kerchner GA, Wang GD, Qiu CS, Huettner JE, Zhuo M (2001a) Direct presynaptic regulation of $\mathrm{GABA} / \mathrm{glycine}$ release by kainate receptors in the dorsal horn: an ionotropic mechanism. Neuron 32:477-488. CrossRef Medline

Kerchner GA, Wilding TJ, Li P, Zhuo M, Huettner JE (2001b) Presynaptic kainate receptors regulate spinal sensory transmission. J Neurosci 21:59_ 66. Medline

Kerchner GA, Wilding TJ, Huettner JE, Zhuo M (2002) Kainate receptor subunits underlying presynaptic regulation of transmitter release in the dorsal horn. J Neurosci 22:8010-8017. Medline

Ko S, Zhao MG, Toyoda H, Qiu CS, Zhuo M (2005) Altered behavioral responses to noxious stimuli and fear in glutamate receptor 5 (GluR5)- or GluR6-deficient mice. J Neurosci 25:977-984. CrossRef Medline

Koga K, Sim SE, Chen T, Wu LJ, Kaang BK, Zhuo M (2012) Kainate receptor-mediated synaptic transmissions in the adult rodent insular cortex. J Neurophysiol 108:1988-1998. CrossRef Medline

Koga K, Descalzi G, Chen T, Ko HG, Lu J, Li S, Son J, Kim T, Kwak C, Huganir RL, Zhao MG, Kaang BK, Collingridge GL, Zhuo M (2015) Coexistence of two forms of LTP in ACC provides a synaptic mechanism for the interactions between anxiety and chronic pain. Neuron 85:377-389. CrossRef Medline

Kung LH, Gong K, Adedoyin M, Ng J, Bhargava A, Ohara PT, Jasmin L (2013) Evidence for glutamate as a neuroglial transmitter within sensory ganglia. PLoS One 8:e68312. CrossRef Medline

Lee CJ, Kong H, Manzini MC, Albuquerque C, Chao MV, MacDermott AB (2001) Kainate receptors expressed by a subpopulation of developing 
nociceptors rapidly switch from high to low $\mathrm{Ca} 2+$ permeability. J Neurosci 21:4572-4581. Medline

Lovinger DM, Weight FF (1988) Glutamate induces a depolarization of adult rat dorsal root ganglion neurons that is mediated predominantly by NMDA receptors. Neurosci Lett 94:314-320. CrossRef Medline

Lucas O, Hilaire C, Delpire E, Scamps F (2012) KCC3-dependent chloride extrusion in adult sensory neurons. Mol Cell Neurosci 50:211-220. CrossRef Medline

Mahadevan V, Pressey JC, Acton BA, Uvarov P, Huang MY, Chevrier J, Puchalski A, Li CM, Ivakine EA, Airaksinen MS, Delpire E, McInnes RR, Woodin MA (2014) Kainate receptors coexist in a functional complex with KCC2 and regulate chloride homeostasis in hippocampal neurons. Cell Rep 7:1762-1770. CrossRef Medline

Mahadevan V, Dargaei Z, Ivakine EA, Hartmann AM, Ng D, Chevrier J, Ormond J, Nothwang HG, McInnes RR, Woodin MA (2015) Neto2null mice have impaired GABAergic inhibition and are susceptible to seizures. Front Cell Neurosci 9:368. CrossRef Medline

Mahajan K, Mahajan NP (2012) PI3K-independent AKT activation in cancers: a treasure trove for novel therapeutics. J Cell Physiol 227:3178 -3184. CrossRef Medline

Mao S, Garzon-Muvdi T, Di Fulvio M, Chen Y, Delpire E, Alvarez FJ, AlvarezLeefmans FJ (2012) Molecular and functional expression of cationchloride cotransporters in dorsal root ganglion neurons during postnatal maturation. J Neurophysiol 108:834-852. CrossRef Medline

Marques JM, Rodrigues RJ, Valbuena S, Rozas JL, Selak S, Marin P, Aller MI, Lerma J (2013) CRMP2 tethers kainate receptor activity to cytoskeleton dynamics during neuronal maturation. J Neurosci 33:18298-18310. CrossRef Medline

Mulle C, Sailer A, Swanson GT, Brana C, O'Gorman S, Bettler B, Heinemann SF (2000) Subunit composition of kainate receptors in hippocampal interneurons. Neuron 28:475-484. CrossRef Medline

Nakamura M, Choi KH, Choi SK, Do CS, Jun JH, Kwon HK, Lee SM, Moon RJ, Yi KJ, Jang IS (2010) Presynaptic kainate receptors increase GABAergic neurotransmission in rat periaqueductal gray neurons. Eur J Pharmacol 635:72-78. CrossRef Medline

Navarro X, Vivó M, Valero-Cabré A (2007) Neural plasticity after peripheral nerve injury and regeneration. Prog Neurobiol 82:163-201. CrossRef Medline

Ng D, Pitcher GM, Szilard RK, Sertié A, Kanisek M, Clapcote SJ, Lipina T, Kalia LV, Joo D, McKerlie C, Cortez M, Roder JC, Salter MW, McInnes RR (2009) Netol is a novel CUB-domain NMDA receptor-interacting protein required for synaptic plasticity and learning. PLoS Biol 7:e41. CrossRef Medline

Palacios-Filardo J, Aller MI, Lerma J (2016) Synaptic Targeting of Kainate Receptors. Cereb Cortex 26:1464-1472. CrossRef Medline

Palecek J, Neugebauer V, Carlton SM, Iyengar S, Willis WD (2004) The effect of a kainate GluR5 receptor antagonist on responses of spinothalamic tract neurons in a model of peripheral neuropathy in primates. Pain 111:151-161. CrossRef Medline

Pan YA, Misgeld T, Lichtman JW, Sanes JR (2003) Effects of neurotoxic and neuroprotective agents on peripheral nerve regeneration assayed by timelapse imaging in vivo. J Neurosci 23:11479-11488. Medline

Partin KM, Patneau DK, Winters CA, Mayer ML, Buonanno A (1993) Selective modulation of desensitization at AMPA versus kainate receptors by cyclothiazide and concanavalin A. Neuron 11:1069-1082. CrossRef Medline

Perlson E, Hanz S, Ben-Yaakov K, Segal-Ruder Y, Seger R, Fainzilber M (2005) Vimentin-dependent spatial translocation of an activated MAP kinase in injured nerve. Neuron 45:715-726. CrossRef Medline

Qiu CS, Lash-Van Wyhe L, Sasaki M, Sakai R, Swanson GT, Gereau RW 4th (2011) Antinociceptive effects of MSVIII-19, a functional antagonist of the GluK1 kainate receptor. Pain 152:1052-1060. CrossRef Medline

Rozas JL, Paternain AV, Lerma J (2003) Noncanonical signaling by ionotropic kainate receptors. Neuron 39:543-553. CrossRef Medline

Sahara Y, Noro N, Iida Y, Soma K, Nakamura Y (1997) Glutamate receptor subunits GluR5 and KA-2 are coexpressed in rat trigeminal ganglion neurons. J Neurosci 17:6611-6620. Medline

Saijilafu, Hur EM, Liu CM, Jiao Z, Xu WL, Zhou FQ (2013) PI3K-GSK3 signalling regulates mammalian axon regeneration by inducing the expression of Smad1. Nat Commun 4:2690. CrossRef Medline

Sang CN, Hostetter MP, Gracely RH, Chappell AS, Schoepp DD, Lee G, Whitcup S, Caruso R, Max MB (1998) AMPA/kainate antagonist LY293558 reduces capsaicin-evoked hyperalgesia but not pain in normal skin in humans. Anesthesiology 89:1060-1067. CrossRef Medline

Sang CN, Ramadan NM, Wallihan RG, Chappell AS, Freitag FG, Smith TR, Silberstein SD, Johnson KW, Phebus LA, Bleakman D, Ornstein PL, Arnold B, Tepper SJ, Vandenhende F (2004) LY293558, a novel AMPA/ GluR5 antagonist, is efficacious and well-tolerated in acute migraine. Cephalalgia 24:596-602. CrossRef Medline

Schindelin J, Arganda-Carreras I, Frise E, Kaynig V, Longair M, Pietzsch T, Preibisch S, Rueden C, Saalfeld S, Schmid B, Tinevez JY, White DJ, Hartenstein V, Eliceiri K, Tomancak P, Cardona A (2012) Fiji: an opensource platform for biological-image analysis. Nat Methods 9:676-682. CrossRef Medline

Sheng N, Shi YS, Lomash RM, Roche KW, Nicoll RA (2015) Neto auxiliary proteins control both the trafficking and biophysical properties of the kainate receptor GluK1. Elife 4.

Simmons RM, Li DL, Hoo KH, Deverill M, Ornstein PL, Iyengar S (1998) Kainate GluR5 receptor subtype mediates the nociceptive response to formalin in the rat. Neuropharmacology 37:25-36. CrossRef Medline

Smith DS, Skene JH (1997) A transcription-dependent switch controls competence of adult neurons for distinct modes of axon growth. J Neurosci 17:646-658. Medline

Sta M, Cappaert NL, Ramekers D, Baas F, Wadman WJ (2014) The functional and morphological characteristics of sciatic nerve degeneration and regeneration after crush injury in rats. J Neurosci Methods 222:189-198. CrossRef Medline

Straub C, Zhang W, Howe JR (2011a) Neto2 modulation of kainate receptors with different subunit compositions. J Neurosci 31:8078-8082. CrossRef Medline

Straub C, Hunt DL, Yamasaki M, Kim KS, Watanabe M, Castillo PE, Tomita $S$ (2011b) Distinct functions of kainate receptors in the brain are determined by the auxiliary subunit Netol. Nat Neurosci 14:866-873. CrossRef Medline

Sung KW, Kirby M, McDonald MP, Lovinger DM, Delpire E (2000) Abnormal GABAA receptor-mediated currents in dorsal root ganglion neurons isolated from $\mathrm{Na}-\mathrm{K}-2 \mathrm{Cl}$ cotransporter null mice. J Neurosci 20:75317538. Medline

Swanson GT, Heinemann SF (1998) Heterogeneity of homomeric GluR5 kainate receptor desensitization expressed in HEK293 cells. J Physiol 513: 639-646. CrossRef Medline

Swanson GT, Green T, Heinemann SF (1998) Kainate receptors exhibit differential sensitivities to (S)-5-iodowillardiine. Mol Pharmacol 53:942949. Medline

Tang M, Pelkey KA, Ng D, Ivakine E, McBain CJ, Salter MW, McInnes RR (2011) Netol is an auxiliary subunit of native synaptic kainate receptors. J Neurosci 31:10009-10018. CrossRef Medline

Tang M, Ivakine E, Mahadevan V, Salter MW, McInnes RR (2012) Neto2 interacts with the scaffolding protein GRIP and regulates synaptic abundance of kainate receptors. PLoS One 7:e51433. CrossRef Medline

Tucker BA, Rahimtula M, Mearow KM (2008) Src and FAK are key early signalling intermediates required for neurite growth in NGF-responsive adult DRG neurons. Cell Signal 20:241-257. CrossRef Medline

Usoskin D, Furlan A, Islam S, Abdo H, Lonnerberg P, Lou D, Hjerling-Leffler J, Haeggström J, Kharchenko O, Kharchenko PV, Linnarsson S, Ernfors P (2015) Unbiased classification of sensory neuron types by large-scale single-cell RNA sequencing. Nat Neurosci 18:145-153. CrossRef Medline

Wu LJ, Zhao MG, Toyoda H, Ko SW, Zhuo M (2005) Kainate receptormediated synaptic transmission in the adult anterior cingulate cortex. J Neurophysiol 94:1805-1813. CrossRef Medline

Wu LJ, Xu H, Ren M, Zhuo M (2007) Genetic and pharmacological studies of GluR5 modulation of inhibitory synaptic transmission in the anterior cingulate cortex of adult mice. Dev Neurobiol 67:146-157. CrossRef Medline

Wyeth MS, Pelkey KA, Petralia RS, Salter MW, McInnes RR, McBain CJ (2014) Neto auxiliary protein interactions regulate kainate and NMDA receptor subunit localization at mossy fiber-CA3 pyramidal cell synapses. J Neurosci 34:622-628. CrossRef Medline

Yan D, Tomita S (2012) Defined criteria for auxiliary subunits of glutamate receptors. J Physiol 590:21-31. CrossRef Medline

Zhang W, St-Gelais F, Grabner CP, Trinidad JC, Sumioka A, MorimotoTomita M, Kim KS, Straub C, Burlingame AL, Howe JR, Tomita S (2009) A transmembrane accessory subunit that modulates kainate-type glutamate receptors. Neuron 61:385-396. CrossRef Medline 